\title{
Analysis of Strategy Focus vs. Market Share in the Mobile Phone Case Business
}

\author{
Ville Isoherranen ${ }^{1}$, Pekka Kess ${ }^{2}$ \\ ${ }^{1}$ Elektroniikkatie, Oulu, Finland \\ ${ }^{2}$ Department of Industrial Engineering and Management Faculty of Engineering, University of Oulu, Finland \\ E-mail: ville.isoherranen@nokia.com, pekka.kess@oulu.fi \\ Received March 22, 2011; revised April 28, 2011; accepted May 4, 2011
}

\begin{abstract}
This study analyses the case business' strategy focus in relation to its market share development by using the strategy orientation framework. The analysis framework is built to evaluate the characteristics of technology orientation (technology push), market orientation (market pull), customer focus and product focus in the case business. The framework is used to evaluate Nokia mobile phones strategy. Its successful business and business transformations contribute to the selection. The findings show strong product focus in case business strategy with developments towards market-orientation.
\end{abstract}

Keywords: Strategy, Market Share, Strategy Analysis Framework, Strategy Orientation

\section{Introduction}

The increasing power of buyers in highly competitive markets forces companies to get closer to customers in order to maintain their business and to create valueadding solutions to capture more revenue from their customer base [1-3]. Strategy creation and its challenges in highly competitive market has been discussed e.g. by Porter [4], Hamel and Prahalad [5], Moore [6], and Kim and Mauborgne [7].

Technology oriented companies strategy is based on the technology assets or skills their posses. Their drive is to push the new technology to market and create winning strategy by being the first to deploy that technology or the one deploying the most advanced technology in the ongoing race of technology innovations [5,6]. Market orientated companies, focused on market pull, are having long-term commitment to understand customer needs, and thus developing innovative solutions by discovering hidden customer needs and new markets [8,9]. Enterprises in all industry areas want to be more customercentric. Customer focus in strategy can e.g. appear as mass customization or personalization strategies [10]. Customer focus can be seen as organization strategy to respond to customers expressed demand [8]. Product focused strategy can be seen as internally focused company's strategy that pursuits competitive advantage by delivering cutting-edge products with best features, based its core-competences [3].

This strategy orientation (technology orientation, technology push; market orientation, market pull; customer focus and product focus) and its relation to market share, will be analysed and discussed in this study. Analysis framework will be build from on literature references as synthesis. The empirical study will be conducted by analyzing case business strategy using the build framework. Motivation for this study comes from the notion of that there has not been previously build such framework that would combine the orientations with the market share analysis.

The case business NOKIA is an old Finnish company. Company has been founded in 1865. In 1995, it focused on telecommunication businesses and in 2007 in mobile phone products and services, when the network systems business merged with Siemens and Nokia Siemens Networks was established. Nokia is the global leader in mobile telecommunications and has dominated the telecom market for years. Nokia shipped 2009 over 430 million units of mobile devices, average of over 1.1 million units a day and thus reaching market share of estimated 35\% of mobile devices market [11]. The transformation of Nokia from a company constructed of several different business areas, such as car tyres, cables, TV's and industry electronics, to company that has focus on telecommunication has been remarkable. Nokia made strategic decision to focus on one of its business areas, and has 
been able to grow significantly due to this strategic choice. Especially, this choice has been followed by long growth in sales of Nokia's mobile phones and thus Nokia has gained leading market position in mobile phone market. This success and growth makes Nokia mobile phone business interesting case example to study strategy orientation during life cycle phases due to its ability to maintain competitiveness. In addition, the ongoing transformation of Nokia from mobile phones focused company to also as a provider of internet-based services, also make Nokia's mobile phone business relevant research case for strategy orientation in reference to life cycle position. Nokia's strategy has been especially discussed by Doz and Kosonen [12], from the viewpoint of strategic agility. Other academic papers written about Nokia cover e.g. topics from open innovation and innovation networks [13], Nokia's growth success factors [14], and the fundamental change that Nokia brough to telecommuniation industry [15].

This study can be condensed to the following research questions:

RQ1: What is the framework to analyze strategy orientation vs. market share?

RQ2: How does the case business strategy orientation change in relation to market share?

This articles theory section is constructed by the introductions of the four strategy orientations, followed by summary presentation of the orientation characteristics, and then deriving the analysis framework. In the empirical part of this paper the research process is presented followed by results and analysis. Last two sections describe the managerial implications together with the research conclusions.

\section{Strategy Orientations}

\subsection{Technology Orientation, “Technology Push”}

Technology push is a term used for the approach in which the technology innovation is pushed to the market starting from internal development via production to marketing function. In the "market pull" approach in the other hand the signal for development starts from the expressed market need [16]. This is illustrated in the Figure 1. Due to nature of this approach, the technology orientation focus in strategy, pushing new technology to market, which has not expressed explicitly its demand for such technology, creates greater uncertainty for success in the marketplace. Technology orientation characteristics are large research and development investments, drive for big leap in the technology development, long term focus and duration of development projects. Also not only there is uncertainty of the market demand, but

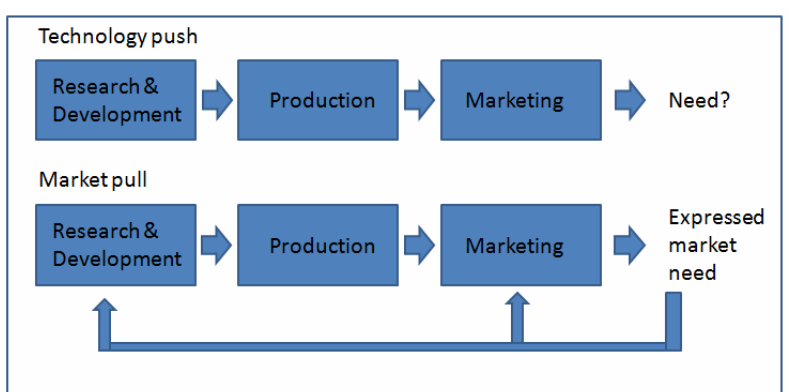

Figure 1. Technology push vs. Market pull (adapted from Martin, [19]).

also about the technology itself, its feasibility and maturity [17-19].

According to Walsh et al. [20] the technology push strategy can based both, on the company's internal competences, or on the external signal of disruptive technology. The internal development can lead to new technology or major improvement of existing one, the technology push originated from external source leads to creative destroying of old technologies. Overall the technology oriented strategy wants to create competitive advantage from the technology advancements and from the adoption of new technologies [21].

\subsection{Market Orientation “Market Pull”}

Brem and Voigt [22] summarize "the market pull to be characterized by unsatisfied customer that creates new demand, which requires problem solving”. The impulse comes from individuals or groups that state their demand. According to Day [23] market-driven companies know their markets deeply so that they are able to identify valuable customers. Thus these companies are able to make strategic choices and implement those consistently. Day [9] also adds that market orientation represents superior skills in understanding and satisfying customers. According to Day [23] the characteristics of marketdriven organizations are offering superior solutions and experience, focus on customer value, ability to convert customer satisfaction into loyalty, drive to energize employees, anticipation of competitor moves by intimate market understanding, viewing marketing as investment and not as costs and leveraging brands assets. Also Day [9] lists the market-driven company features to be a set of beliefs that puts customer's interest first, ability to generate and use information about customers and competitors, and the ability to coordinate resources for customer value creation. Slater and Narver [24] summarize market orientation to be continuous collection of target customers' needs and competitors' capabilities. Hartline et al. [25] state "market orientation to be organizational 
culture that creates effectively and efficiently superior value to buyers and thus excellent business performance”. Slater and Narver [8] describe the market-oriented approach to be "long-term, proactive, commitment to understand customer needs, both expressed and latent, and develop innovate solutions for ensuring high customer value”. At the same time, market-oriented companies, understanding that different types of customers provide different levels of information and that customer voice is only one source of information for building strategies. The market-oriented approach enables companies to deliver market focused innovation and sustainable competitive advantage by their commitment to continuous market learning, discovering latent needs and hidden markets [8].

Here we define the market pull strategies characteristics to be synonymous of market-oriented and market-driven strategy characteristics (Figure 1).

\subsection{Customer Focus}

Tseng and Piller [10] present the customer focus to be putting the customer at the center of the enterprise and building processes and systems towards serving customers as individuals. Customer culture within organization is basically thinking the key decisions, key investments and key processes from customer point of view. It is about putting the customer first both in everyday business operations and from strategic planning initiatives. This is done based on company's the inbuilt values, behavior models and competences which in the end make the culture of a company to be customer focused [26]. Slater and Narver [8] differentiate the customer-led and market oriented as customer-led is seen as reactive approach that focuses on the expressed desires of customers and fails to deliver sustainable competitive advantage by failing to recognize the not stated customer requirements, which can be source for innovations. However, Connor [27] criticizes this approach to not to be taken into consideration the firms size as factor, and with neglecting the short term survival needs of businesses, thus these approaches need to be in balance. In response Slater and Narver [28] clarify their position of stating the nature of continuum of market learning, and that exclusively customer-led companies do not achieve full benefits of being market-oriented. And they draw comparison with Miles et al. [29] typology of which any chosen strategy may be successful, but that in market-orientation strategy continuum the more advanced businesses do better. Hartline et al. [25] defines to customer orientation to be a set of beliefs that puts the customer's interest first, but balancing this with other stakeholder's requirements, and they also combine the aspects of customer orientation to market orientation. Kelly [30] concludes that "customer focus can be result of mutually beneficial long-term relationship with customers".

Mass customization and personalization approaches are the essential characteristics of customer focus in the strategy level. The basic idea of being customer centric in mass customization is to achieve the individual customer requirements without any significant increase in production or distribution costs. The competitive advantage of mass customization is based on combining the efficiency of mass production with the differentiation possibilities. Also the agile manufacturing, focused factories, flexible specialization, lean manufacturing, customer relationship management can be presented as the strategies for fulfilling the changing customer requirements [10].

Mass customization characteristics include stable process that is not re-invented for each customer but that main process is flexible enough to produce based on the needs of the different customers. Also there is pre-build "solution base" which sets the boundaries for differentiation. Also there is focus on the relationship building by e.g. collecting of data of the customer needs and requirements. The overall customization is kept under cost control so that the price does not increase resulting in possible market segment switch [10].

Personalization characteristics include frequent communication and interaction with the customer. The process is information intense, and has been especially adopted in the internet based services business. The information of the customer is exchanged to product features or attributes. The recommendation plays important role in personalization strategy. Recommendation based on customer attributes can be used to propose set or bundle from the existing standard products, which created added value for customer with minimum effort. This capability to delivery personal configuration is one of the key parts of building personalization in to strategy [10].

We define customer focus in strategy in this research to have the characteristics of customer centric approach, mass customization and personalization (Figure 2).

\subsection{Product Focus}

Galbraith [3,31] defines the characteristics of product-centric company from 13 different viewpoints. We consider the most important views from strategy point of view to be the goal, value creation route, customer definition, organizational setup, reward priorities, the priority setting basis and the pricing. Also the aspects of organizational setup and reward priorities together with measurement of success are essential aspects to consider. Ac- 


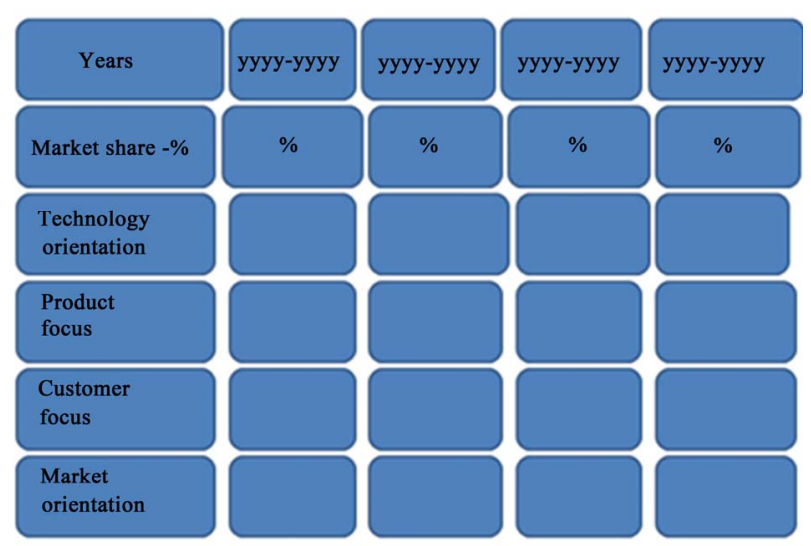

Figure 2. Strategy orientations vs. market share analysis framework.

cording to Galbraith the goal of product product-centric company is to create the best product for customer. The value creation route is the cutting-edge products, useful features and new applications. Highest customer priority is given to most advanced customers. The organizational setup focuses on product profit centers and the reward focuses e.g. on the market share. The priority setting of is based on portfolio of products. Thompson [2] describes the transformation journey of inward-focused product driven company via market-focused company to customer-centric company. The characteristics of company focused on the core competences, with certain inward-focus, also can be identified as part of the product-focused company [5].

We define the product focused in strategy in this research to have the characteristics of product-oriented company.

\subsection{Framework}

We have summarized based on the literature analysis the main characteristics of the strategy orientations of technology orientation, market orientation, customer focus and product focus to Table 1.

Based on this collection we have created strategy orientation framework that will use for analysis (Figure 2). In this framework the different orientation characteristics are fitted together. The sections are named with the characterizing heading from Table 1. The framework highlights the trade-off nature of the different orientations or focus directions but orientations can also coexist within strategy focus.

\section{Empirical Study}

\subsection{Research Process}

The research process is described in the Figure 3. The strategy orientations were studied by using existing literature as a source. The output of the literature review was the synthesis in form of the analysis framework. This phase where followed by the case material empirical data collection. This empirical data was collected from the annual reports of the case business through the years 1990-2009. This empirical data consisted of 20 case business annual reports (Appendix 1). Time span of nearly 20 years was considered to be sufficiently wide in the fast changing telecommunication markets and to bring extensive knowledge on the case business strategy development. These reports where available in printed format in Finnish and in electronic format both in Fin-

Table 1. Strategy orientation characteristics summary

\begin{tabular}{|c|c|c|c|c|}
\hline $\begin{array}{l}\text { Strategy Orientation } \\
\text { Characteristics }\end{array}$ & $\begin{array}{l}\text { Technology Orientation } \\
\text { "Technology Push" }\end{array}$ & $\begin{array}{l}\text { Market Orientation, } \\
\text { "Market Pull" }\end{array}$ & Customer Focus & Product Focus \\
\hline & $\begin{array}{l}\text { 1) Large research and } \\
\text { development investments }\end{array}$ & $\begin{array}{l}\text { 1) Ability to identify } \\
\text { customers }\end{array}$ & $\begin{array}{l}\text { 1) Focus on ex- } \\
\text { pressed customer } \\
\text { needs }\end{array}$ & $\begin{array}{l}\text { 1) Focus on creation of } \\
\text { best product }\end{array}$ \\
\hline & $\begin{array}{l}\text { 2) Drive for big } \\
\text { advancements in } \\
\text { technology }\end{array}$ & $\begin{array}{l}\text { 2) Focus on customer } \\
\text { value }\end{array}$ & $\begin{array}{l}\text { 2) Stable customiza- } \\
\text { tion process with } \\
\text { boundaries }\end{array}$ & $\begin{array}{l}\text { 2) Focus on features and } \\
\text { new applications }\end{array}$ \\
\hline & $\begin{array}{l}\text { 3) Long term focus and } \\
\text { duration of development } \\
\text { initiatives }\end{array}$ & $\begin{array}{l}\text { 3) Ability to generate } \\
\text { information about } \\
\text { customers }\end{array}$ & $\begin{array}{l}\text { 3) Collecting data } \\
\text { and requirements of } \\
\text { customer needs }\end{array}$ & $\begin{array}{l}\text { 3) Creation of portfolio } \\
\text { of products }\end{array}$ \\
\hline & $\begin{array}{l}\text { 4) Adoption of new } \\
\text { technologies }\end{array}$ & $\begin{array}{l}\text { 4) Long-term proac- } \\
\text { tive drive to under- } \\
\text { stand customer needs }\end{array}$ & $\begin{array}{l}\text { 4) Cost focused cus- } \\
\text { tomization and dif- } \\
\text { ferentiation }\end{array}$ & $\begin{array}{l}\text { 4) Inward-focused strat- } \\
\text { egy approach, 'core } \\
\text { competences' }\end{array}$ \\
\hline
\end{tabular}




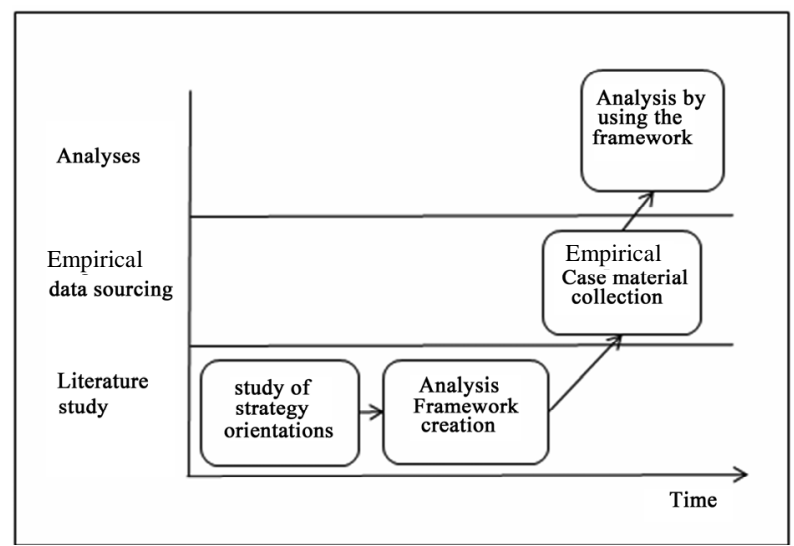

Figure 3. The research process.

nish and English. Both the printed and electronic version where used to achieve rich insight on the case business strategy. After this collection phase, the market share data was sourced from the global market analytics (Appendix 2, [32]). The data was available from years 1998 to 2009. This then gave the time span scope for the empirical study even when there were older annual reports available. The created strategy orientation framework was then used to analyze the empirical case data. The analysis was conducted in four parts (Figure 4) to reflect the case business strategy focus in different market share positions. The phase's selection and timing was based on the analysis done in the previous research and due to the availability of market share data.

\subsection{Results and Analysis}

The period of 1998-2000 the case business has the characteristics of the technology oriented strategy which can be seen as the continuance of the large investments to research and development, followed by focus on international standardization of new technologies. However the dominating characteristics are the product focus in the strategy. This is visible with the focus on the development of portfolio of products for to satisfy the needs of different segment on customers. Especially the corporate users' and private users' needs are identified. Case business aims for developing the best product with high focus on the e.g. design and latest features of mobile phones. During this period also the customer focus, in form of regional organizations and the mass customization needs are raising. There is example e.g. of the customization of the mobile phone keyboard for Chinese users. Differentiation is driven by differences in customer base as the different customer requirements are being collected. The case business market share develops strongly in this period from $22.9 \%$ to $30.6 \%$.

The period of 2001-2003 the case business continues

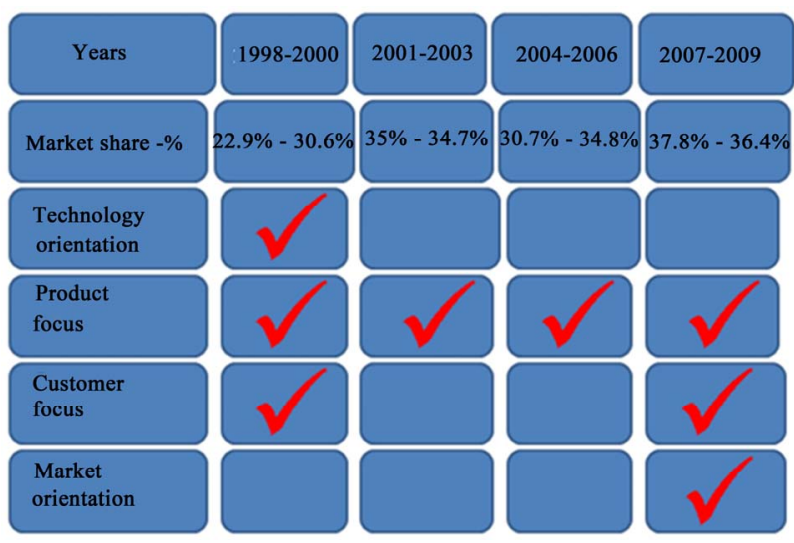

Figure 4. Strategy orientation vs. market share analysis of the case business

to have strong product focus in the strategy. Also there is less mentioned about the customer focus. The strategy focus seems to be focused on the internal development initiatives and moreover the development of widening product portfolio. During 2001 there is launched 22 new mobile phone models, 200234 new mobile phone models, and e.g. during 2003, 2005 and 2006 staggering about 40 new mobile phone models on each year. The strategy orientation is considered to be in this period very much product focused. The case business market share starts from the $35.1 \%$ at keeps quite stabile during this period.

The period of 2004-2006 the case business focuses on development of new features and responding the different customer needs with large variety of products. Especially there are examples of development of color displays, QWERTY - keyboards, megapixel cameras as new high end features. Also the case business strategy shows drive to find new purposes to use of its products e.g. in the area gaming. The decision to establish new organizational setup of nine product business units to optimize economies of scale and drive for market share gains towards the set long term target shows characteristics of product focused organization. The case business market share declines in the beginning of the period but raises again to $34.8 \%$ by end of the examined period.

The period of 2007-2009 shows indications of change in the case business strategy. The product dimension continues to be strong but the also the market-orientation is becoming visible. There is strategic drive to pursuit development of internet services businesses by acquisition of several companies, e.g. music and navigation services. Also the more long term commitment for understanding customer needs and delivering holistic solutions for their needs is coming visible at the end for the examined period e.g. by establishing dedicated solutions unit. Also there are signs of exclusive customization efforts 
for key customer of certain model. This is consistent with the customer focus characteristics. The case business market share reaches the highest position within the examined period on 2008 with 38.6\% share, but is followed by decline towards the end of the examined period.

The strategy focus development of the case business is summarized in the Figure 4.

\section{Managerial Implications}

The strategy analysis framework (Figure 2) build from literature references combines the two dominating dimensions in the current strategy thinking: the market based (demand based) strategies and the product based strategies. Examples of the market based strategies can be found from the thinking of Porter [4] (differentiation or cost leadership) and the thinking of Hamel and Prahalad [5] (core competences) presents good example of the product-based strategies. This framework enables analysis in both of these domains by identification of key characteristics. Product level strategies that in many occasions derive from company's core competences of technology (technology push), and the product-centric strategies, make the analysis framework's product based strategies section. The market based strategies section is build from the customer focused strategies and market-oriented strategies (market pull).

The strategy orientation analysis framework enables managers responsible of strategy development to analyze their company's position in the demand-based or product-based domains, and then more accurately to point the position to one of the four directions. Also not only the current position but the change over time in the company's strategy position can be analyzed using this analysis framework in relation to market share development. The same framework can be applied to analyze or estimate the competitor's strategy position, which is important in highly competitive markets to ensure competitive advantage.

The case business strategy orientation dynamics give interesting case example of the strategy development over time. This is good benchmark for strategy developers in different companies as the agility to change the strategy drivers has clearly showed in the case business example to be essential for the successful growth, and then later in the life cycle to be the essential building block for renewal and search for new growth.

Overall the discussion of the customer-centricity within the company can be easily evaluated by using the analysis framework. Companies founding themselves in the section of technology-product orientation cannot argue to be leading in customer-centricity and vice versa.
This practical analysis tool gives for strategy analysts to frame to evaluate of how the company is doing with its strategy implementation, contrast in the desired and current state, gives strong signal and highlights the difficulty to achieve customer-centricity. Customer-centricity, however, is more and more important in the market where buyers have variety of choice and failure to meet the customer requirements may result in loosing valuable customers, and in the end going out of business.

\section{Conclusions}

The purpose of this study was to analyze the case business strategy orientations versus markets share development. The analysis framework was build from literature references and the framework was tested with case business strategy evaluation.

The research questions were stated to be following:

RQ1: What is the framework to analyze strategy orientation vs. market share?

RQ2: How does the case business strategy orientation change in relation to market share?

Answering to research questions:

RQ1: The framework to analyze the strategy orientation versus markets share is presented in the Figure 4.

RQ2: The case business strategy orientations change in relation to market share is presented in the Figure 4. The case business starts with the strategy orientations towards technology oriented strategy and moves towards product focused strategy. In the end of the examined period the case business is moving towards market orientation and customer focus in the strategy orientation.

The limitations of this research are originated from the definitions of analysis framework dimensions. Especially the definition of customer focused and market oriented are somewhat overlapping in some areas. The customer-centric strategies are in the field of strategy research quite new and there is discussion ongoing on the fundamental definitions and directions. Also the empirical material has limitations due to its nature, as it gives overview on the examined period but many detailed or fine scale notations cannot be examined in further details. The view in this research is breath but shallow, in comparison to e.g. interview approach in empirical material collections where it is deep but narrow.

The areas for further research include the more indepth analysis of the customer focused, customer centric approach on strategy, as well as the customer influence in strategy priorities definitions, customer lifetime value approach on the strategy and the overall transformation journey from product-centric strategy towards customercentric strategy. 


\section{References}

[1] R. C. Whiteley, "The Customer Driven Company: Moving from Talk to Action,” Perseus Books Group, New York, 1991.

[2] H. Thompson, "The Customer-Centered Enterprise," McGraw-Hill, New York, 2000.

[3] J. R. Galbraith, "Designing the Customer-Centric Organization,” Jossey-Bass, San Francisco, 2005.

[4] M. E. Porter, "Competitive Advantage,” The Free Press, New York, 1985.

[5] G. Hamel and C. K. Prahalad, "Competing for the Future,” Harward School Press, Boston, 1994.

[6] G. A. Moore, "Living on the Fault Line," Harper Business, New York, 2000.

[7] W. C. Kim and R. Mauborgne, "Blue Ocean Strategy," Harvard Business School Press, Boston, 2005.

[8] S. F. Slater and J. C. Narver, "Customer-Led and Market-Oriented: Let's Not Confuse the Two,” Strategic Management Journal, Vol. 19, No. 10, 1998, pp. 10011006.

doi:10.1002/(SICI)1097-0266(199810)19:10<1001::AIDSMJ996>3.0.CO;2-4

[9] G. S. Day, "The Capabilities of Market Driven Organizations," Journal of Marketing, Vol. 58, No. 4, 1994, pp. 37-52. doi:10.2307/1251915

[10] M. M. Tseng and F. T. Piller, “The Customer Centric Enterprise,” Springer-Verlag, Berlin, 2003. doi:10.1007/978-3-642-55460-5

[11] Strategy Analytics, “Strategy Analytics Insights,” 2009.

[12] Y. Doz and M. Kosonen, "Fast Strategy: How Strategic Agility Will Help You Stay Ahead of the Game,” Wharton School Publishing, Philadelphia, 2008.

[13] K. Dittrich and G. Duysters, "Networking as a Means to Strategy Change: The Case of Open Innovation in the Mobile Telephony," The Journal of Product Innovation Management, Vol. 24, No. 6, 2007, pp.510-521. doi:10.1111/j.1540-5885.2007.00268.X

[14] M. Häikiö, “Nokia-The Inside Story,” Opiskelijakirjaston Verkkojulkaisu, Helsinki, 2002.

[15] D. Steinbock, "The Nokia Revolution: The Story of an Extraordinary Company that Transformed an Industry," AMACOM, New York, 2001.

[16] M. J. C. Martin, "Managing Innovation and Entrepreneurship in Technology-Based Firms," Wiley-IEE, New York, 1994.

[17] G. S. Lynn and S. Heintz, "From Experience: Where does Your New Technology Fit into the Marketplace?” Journal of Production Innovation Management, Vol. 9, No. 1, 1992, pp. 19-25.

[18] G. Hamel and C. K. Prahalad, "Corporate Imagination and Expeditionary Marketing," Harward Business Review, Vol. 69, No. 4, 1991, pp. 81-92.
[19] W. E. Scouder, "Improving Productivity through Technology Push,” Research Technology Management, Vol. 32, No. 2, 1989, pp. 19-31.

[20] S. T. Walsh, B. A. Kirchhoff and S. Newbert, "Differentiating Market Strategies for Disruptive Technologies," IEEE Transactions on Engineering Management, Vol. 49, No. 4, 2002, pp. 341-351. doi:10.1109/TEM.2002.806718

[21] P. Y. K. Chau and K. Y. Tam, "Organizational Adoption of Open Systems: A 'Technology-Push', 'Need Pull' Perspective,” Information \& Management, Vol. 37, No. 5, 2000, pp.229-239. doi:10.1016/S0378-7206(99)00050-6

[22] A. Brem and K.-I. Voigt, "Integration of Market Pull and Technology Push in the Corporate Front End Innovation Management-Insights from the German Software Industry," Technovation, ScienceDirect, Vol. 29, No. 5, 2009, pp. 351-367. doi:10.1016/j.technovation.2008.06.003

[23] G. S. Day, "What does It Mean to Be Market-Driven?" Business Strategy Review, Vol. 9, No. 1, 1998, pp. 1-14. doi:10.1111/1467-8616.00051

[24] S. F. Slater and J. C. Narver, "Market Orientation and the Learning Organization,” The Journal of Marketing, Vol. 59, No. 3, 1995, pp. 63-74. doi:10.2307/1252120

[25] M. D. Hartline, J. G. Maxham and D. O. McKee, "Corridors of Influence in the Dissemination of Customer-Oriented Strategy to Customer Contact Service Employees,” Journal of Marketing, Vol. 64, No. 2, 2000, pp. 35-50. doi:10.1509/jmkg.64.2.35.18001

[26] O. Botero, "Customer Culture: It All Starts and Ends with Listening," 29 May 2007. http://www.customerthink.com/article/customer_culture_ starts_ends_with_listening

[27] T. Connor, "Customer-Led and Market-Oriented: A Matter of Balance,” Strategic Management Journal, Vol. 20, No. 12, 1999, pp. 1157-1163. doi:10.1002/(SICI)1097-0266(199912)20:12<1157::AID$\underline{\mathrm{SMJ} 72>3.0 . \mathrm{CO} ; 2-3}$

[28] S. F. Slater and J. C. Narver, "Market Oriented Is More than Being Customer-Led,” Strategic Management Journal, Vol. 20, No. 12, 1999, pp.1165-1168. doi:10.1002/(SICI)1097-0266(199912)20:12<1165::AIDSMJ73>3.0.CO;2-\#

[29] R. E. Miles, C. C. Snow, A. D. Meyer and H. J. Coleman, "Organizational Strategy, Structure and Process," The Academy of Management Review, Vol. 3, No. 3, 1978, pp. 546-562.

[30] S. W. Kelly, "Developing Customer Orientation among Service Employees," Journal of the Academy of Marketing Science, Vol. 20, No. 1, 1992, pp. 27-36. doi:10.1007/BF02723473

[31] J. R. Galbraith, "Designing the Customer-Centric Organization,” Jossey-Bass, San Francisco, 2005.

[32] Gartner, “Analytics Insights,” 2011. 
Appendix 1

\begin{tabular}{ccc}
\hline \multirow{2}{*}{ Year } & \multicolumn{2}{c}{ Number of Pages } \\
\cline { 2 - 3 } & Annual report & $\begin{array}{c}\text { CEO's/Board of } \\
\text { Directors Report }\end{array}$ \\
\hline 1990 & 72 & 2 \\
1991 & 64 & 2 \\
1992 & 64 & 2 \\
1993 & 64 & 2 \\
1994 & 71 & 2 \\
1995 & 72 & 2 \\
1996 & 76 & 3 \\
1997 & 80 & 2 \\
1998 & 56 & 2 \\
1999 & 52 & 2 \\
2000 & 42 & 4 \\
2001 & 56 & 4 \\
2002 & 66 & 3 \\
2003 & 70 & 3 \\
2004 & 78 & 3 \\
2005 & 83 & 3 \\
2006 & 87 & 5 \\
2007 & 86 & 5 \\
2008 & 89 & 5 \\
2009 & 98 & 5 \\
TOTAL & $\mathbf{1 4 2 6}$ & $\mathbf{6 1}$ \\
\hline & &
\end{tabular}

Appendix 2

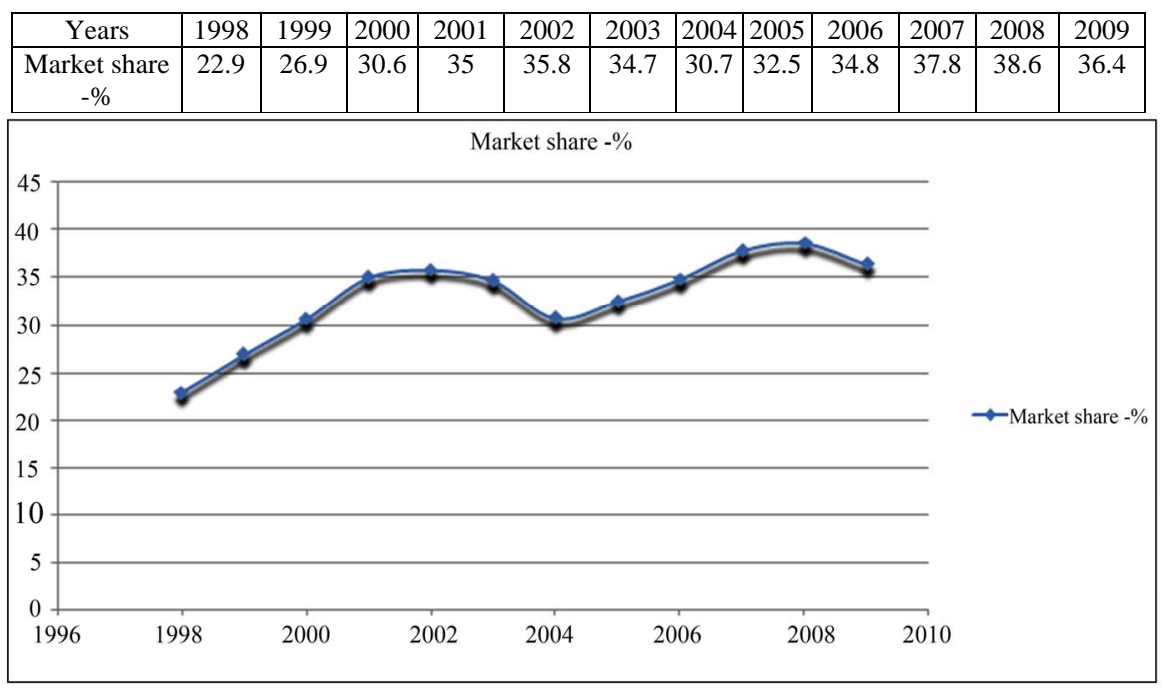

